\title{
Filmlerde Kutsal Kitap: “The Book of Eli” Örneği
}

\author{
Scripture in Movies: The Case of "The Book of Eli"
}

\section{Halil ibrahim Şenavcu* $\odot$}

\section{Öz}

Kutsal kitapların günümüzde hak ettiği değeri görmesi için çeşitli vasıtalarla din adamları, dinlerin mensupları ve dinî kurumlar tarafindan vurgu yapıldığı görülmektedir. Bu yollardan biri olarak seçilen film/sinema, görselliğin ön planda olduğu çağımızda kullanışlı ve kıymetli bir araç olarak ortaya çıkmaktadır. Film, dinî mesajların doğrudan ve/veya dolaylı yollardan bilinçaltına işlenmesi şeklinde kullanılan bir vasıta olmuştur. Albert ve Allen Hughes kardeşlerin yönettiği, ünlü aktör Denzel Washington'ın başrolünü üstlendiği “The Book of Eli” (Tanrı'nın Kitabı) filmi, Hıristiyanlıktaki Tanrı, peygamber, kutsal kitap ve insan anlayışı hakkında önemli bilgiler içermektedir. Film hem Hıristiyanlara kendi kutsal kitaplarına daha fazla değer vermeleri gerektiği fikrini aşılamakta hem de diğer dinlerin müntesiplerine, bu kitabı uygulayan kişilerin dünyayı nasıl yönetebileceği, yani ne kadar önemli bir kitaba sahip oldukları mesajını vermektedir. Bu filmin, kutsal kitap vurgusuyla birlikte verdiği başka mesajlar da vardır. Bunların en önemlileri, eskatolojik, apokaliptik vurgular ile seçilmiş bir elçinin Tanrı tarafindan her şartta korunacağı ve mesaj yerine ulaştırılıncaya kadar destekleneceği fikridir. Aynı zamanda filmde arka planda, deizm düşüncesinin aksine, insanları başıboş bırakmayacak bir Tanrı düşüncesi de işlenmektedir. Bu çalışma, mezkûr film örneğinde, filmlerde dinî öğelerin kullanılması, mesajların verilmesi ve kutsal kitapların değerinin vurgulanmasının keyfiyeti hususunda bir analiz yapmayı amaçlamaktadır.

\section{Anahtar Kelimeler}

Film, Sinema, Dini Mesaj, Hıristiyanlık, Tanrı'nın Kitabı

\begin{abstract}
It is seen that the holy books are emphasized by religious institutions, clergy or religious people through various means in order to see the value they deserve, as they used to, again today. Film/cinema, chosen as one of these ways, emerges as a useful and valuable tool in our age when visuality is at the forefront. Film/cinema has also been a tool used to convey religious messages both directly and indirectly to the subconscious. "The Book of Eli", directed by brothers Albert and Allen Hughes and starring the famous actor Denzel Washington contains important information about God, the prophet, the holy book, and human understanding in Christianity. The Film both instilled in Christians the idea that they should value their own scriptures more and gave the message to members of other religions about how the people who practice it can rule the world, that is, how important a book they have. This study aims to make an analysis of the use of religious elements in films, how to give messages and to emphasize the value of holy books in the aforementioned film example.
\end{abstract}

\section{Keywords}

Film, Movie, Cinema, Religion, Christianity, The Book of Eli

\footnotetext{
* Sorumlu Yazar: Halil ỉbrahim Şenavcu (Dr. Öğr. Üyesi), İzmir Kâtip Çelebi Üniversitesi, İslami illimler Fakültesi, Felsefe ve Din Bilimleri Bölümü, İzmir, Türkiye. E-Posta: ibrahimsenavcu@hotmail.com ORCID: 0000-0003-2096-3093
}

Atf: Halil Ibrahim Senavcu, "Filmlerde Kutsal Kitap: “The Book of Eli” Örneği,” darulfunun ilahiyat 31, 1 (2020): 99-118. https://doi.org/10.26650/di.2020.31.1.0042 


\section{Extended Summary}

Holy books/scriptures have an important position for religions. Various ways are used to emphasize the value of the scriptures. One of these ways is that films that appeal to all segments and are made in an immersive nature with today's technology. Since their inception, cinema and films have been put forward for various purposes such as informing, entertaining, intimidating, thinking, protesting and giving messages by presenting real-life sections. Films sometimes aim to give positive behaviors by giving religious/moral messages and/or to support the culture of living together among people of different beliefs. It is also seen that these messages are processed with the idea of pushing people to question current practices in both religious and real-life (such as the legal system).

Films are preferred to provide information about different religions, as well as to emphasize the importance of the sacred objects of those religions to the members of that religion. The religious messages in films may not only be directed towards the believers of a single religion, but at the same time, believers of other religions may be included in order to draw them closer to the religion in question by using these religious messages. This may also at least prevent the antipathetic view of their religion. Film screenwriters, producers, and directors can also engage in some kind of missionary activity by positively influencing the audience in line with their beliefs. More often than not, a film may incorporate a critical approach towards some popular beliefs and superstitions, which are not considered to be pertaining to the 'true' religion, by putting them into comical or tragicomical contexts. These religious elements in films can be given directly to the audience, as well as in the form of messages processed in the background. In fact, some viewers who watch films of the latter kind may not even be aware of these religious messages. However, the message may be involuntarily embedded in the subconscious of these people.

Various films have been made about the sacred elements and objects of Christianity. In fact, most of the scenes of some of these films can be interpreted in the form of the transmission of some parts of the Christian Bible to the screen. The best examples are the Passion of the Christ (2004), directed by Mel Gibson, and Noah (2014), starring Russell Crowe. One of the films in which the messages of Christianity are directly processed is the film The Book of Eli, which was released in 2010 and is understood to have been made to realize the value of the holy book.

The main message that is especially emphasized in the Book of Eli film is that the word/message/Book of God will not disappear from the earth forever and that there will surely be a messenger to carry this message. In the film, there is a struggle for protection and possession of a precious book (the Bible) in order to take control and rule everyone in a world where very few people live as a result of a huge explosion in a post-apocalyptic 
time. It is also mentioned in the film how people can have relationships in such an environment and what ways and methods they can apply to meet their needs. Even here, the message that gets across to the audience can be interpreted as an exceptionally Christian idea, if we accept the subtext that the absence of the Book or a prophet would necessarily result in the relapse of humanity to their 'old' vagrant, lawless and ruthless ways of pre-Christian times.

There are other side messages that the film gives along with the emphasis on the holy book. The most important of these is concerned with the eschatological and apocalyptic emphasis on the end of the world, accompanied by the idea that a messenger chosen from among the people will be protected by God in every condition and supported until the message is successfully delivered. The idea of a God that will not leave people (at least for a very long time) adrift is also rendered in the background of the film. This, in fact, contradicts deism, which possesses the idea of God, who is not involved in anything else after creating humans.

Finally, it should be stated that the film The Book of Eli is a good example of the processing of religious messages and the emphasis on the value of holy books in films. It can be said that the messages left a lasting effect on the minds as a result of the processing of the messages in a very immersive way and the Christian thought on the subject, the holy book, the understanding of God and the prophet were successfully delivered. 


\section{Giriş}

Dinler için kutsal kitaplar, insanların hayatlarına yön verme, geçmiş ve gelecek tasavvurlarını ve buna bağlı davranışlarını etkileme, kutsal(lar)la bağ kurma, onları okuyarak ibadetlerini gerçekleştirme gibi nedenlerden dolayı önemli bir konuma sahiptir. Bununla birlikte neredeyse her inancın din adamlarınca 'sekülerleşen dünyamızda kutsal kitapların değerinin eskisi kadar bilinmemesi' konusunda bir yakınma duymak mümkündür. Kutsal kitapların değerinin vurgulanması için çeşitli yollara başvurulduğu görülmektedir. Bu yollardan biri ise, her kesime hitap eden günümüz teknolojisiyle sürükleyici nitelikte çekilen filmlerdir.

Ortaya çıktığı günden bugüne sinema ve filmler, gerçek hayattan kesitler sunarak bilgilendirme, eğlendirme, korkutma, düşündürme, protesto etme, mesaj verme gibi çeşitli amaçlar için kullanılmıştır. ${ }^{1}$ Filmler bazen dinî/ahlakî mesajlar vererek olumlu davranışlar kazandırmayı bazense farklı inançlara mensup insanlar arasında bir arada yaşama kültürünü desteklemeyi amaçlamıştır. ${ }^{2}$ Bu mesajların gerek dinsel gerekse reel hayattaki (mesela hukuk sistemi gibi) mevcut uygulamalar konusunda insanları sorgulamaya itmesi düşüncesiyle işlendiği de görülmektedir. ${ }^{3}$

Filmlerde vurgulanan dinî öğeler, hem ilgili filmi çekenlerin dinlerinin müntesiplerini kendi inançlarına daha sıkı bağlamak hem de başka dinlere mensup kişilere o dini daha sevimli göstermek ve böylece rahatça o dini başkalarına aktarabilmek/yayabilmek (misyonerlik/tebliğ) vb. faaliyetler için de kullanılmaktadır. Filmlerdeki dinî öğeler izleyiciye doğrudan aktarılabildiği gibi arka planda işlenen mesajlar şeklinde de verilebilmektedir. Hatta ikinci türden filmleri izleyen bazı seyirciler işlenen bu dinî mesajlardan haberdar dahi olmayabilmektedirler. Ancak verilmek istenen mesaj bu kişilerin bilinçaltına istem dışı bir şekilde yerleşmektedir. ${ }^{4}$ Filmler vasıtasıyla verilen bilgi ve mesajların pek çok insanda kitap okumaktan daha fazla etki bıraktığı ve kalıcı olduğu da araştırmalar sonucunda tespit edilmiştir. ${ }^{5}$

1 William L. Blizek, "Sinema Filmleri ve Din,” çev. Bilal Yorulmaz, Marmara Üniversitesi İlahiyat Fakültesi Dergisi 47, sy 47 (2014): 193-202; Bilal Yorulmaz, Sinema ve Din Eğitimi, 2. bs (Dem Yayınları, 2016).

2 Asife Ünal, “Uyumlu Bir Dünya İnşası Bağlamında Sinema ve Din İlişkisi: 'Life of Pi’ Örneği,” International Journal of Sport Culture and Science 3, sy Special Issue 4 (15 Eylül 2015): 567, 580-81; Murat Dural, “Aamir Khan Filmlerinde Dini Öğeler” (Yüksek Lisans Tezi, İzmir Kâtip Çelebi Üniversitesi, 2018).

3 Dural, “Aamir Khan Filmlerinde Dini Öğeler”.

4 Blizek, "Sinema Filmleri ve Din”; Yüksel Balaban, "Miyazaki Sinemasında Şintoizm Göstergelerinin Sunumu,” içinde Sinema ve Din (İstanbul: Dem Yayınları, 2015), 287-88.

5 Muhammed Veysel Bilici, "Hollywood Filmlerindeki Apokaliptik Temalar: Sinema, Popüler Kültür ve Din,” Milel ve Nihal 4, sy 2 (2007): 139-41, 144-45. 
Hıristiyanlık için kutsal sayılan öğeler ve nesneler hakkında çeşitli filmler çekilmiştir. Hatta bunlardan bazıları bizzat Hıristiyan kutsal kitabı Kitab-1 Mukaddes'in bölümlerinin vizyona aktarılması şeklinde olmuştur. Buna en güzel örnekler Mel Gibson'ın yönettiği gişe rekorları kıran 2004 yapımı The Passion of the Christ (Tutku: Hz. İsa'nın Çilesi) filmi ile başrolünü Russell Crowe'un oynadığ1 2014 yapımı Noah (Nuh: Büyük Tufan) filmidir. Hıristiyanlığa dair mesajların doğrudan işlendiği filmlerden özellikle bir tanesi kutsal kitabın değerinin fark ettirilmesi amacıyla çekildiği anlaşılan ve 2010 yılında vizyona giren - ancak günümüze kadar hakkında detaylı akademik bir çalışmanın yapılmadığı- The Book of Eli filmidir.

Bu film ve odaklandığı konu hakkında literatüre bakıldığında Journal of Religion \& Film dergisinde 2010 yılında Adam L. Porter tarafindan yazılan "The Book of Eli" adlı film eleştirisi/yorumu ${ }^{6}$ ile yine aynı dergide 2011 yılında yayımlanan James Aston ve John Walliss'in "The (Un)Christian Road Warrior: The Crisis of Religious Representation in the Book of Eli (2010)" başl1klı makalesi ${ }^{7}$ ve 2016 y1linda yayımlanan Seth M. Walker'a ait “'It's not a F******Book, It's a Weapon!': Authority, Power, and Mediation in The Book of Eli" başlıklı makale ${ }^{8}$ dışında bilimsel bir çalışmaya rastlanılmamaktadır. Bu çalışmalar mezkûr filmi farklı yönlerden ele almış, hatta Aston ve Walliss, Porter'in yorumunu eleştiriye tâbi tutmuşlardır. Araştırmamız literatüre katkı bağlamında Hıristiyan kutsal kitabının değerinin bu film vasıtasıyla vurgulanmasının keyfiyeti ve filmin içerdiği, gerek doğrudan gerekse dolaylı dinî mesajların detaylıca ele alınması bakımından önem taşımaktadır. Bu araştırmanın, filmlerde ve bu filmde çeşitli şekillerde sunulan dinî mesajların ve kutsal kitap vurgusunun ustaca nasıl ve niçin işlendiğini, buna bağlı olarak insanların düşüncelerinde/inançlarında nasıl değişiklik ve yönlendirme hedeflendiğini ortaya koymaktır.

Araştırmamız kapsamında The Book of Eli filmi, eleştirmenlerin yorumları ve özelde bu film, genelde filmlerdeki dinî mesajlar hakkında yazı yazanların çalışmalarıyla birlikte değerlendirmeye tâbi tutularak, filmlerin tarih, din/ler, kültürel, felsefî, psikolojik ve sosyololojik öğe ve bağlantılarıyla amaçlarını

6 Adam L. Porter, "The Book of Eli," Journal of Religion \& Film 14, sy 1 (2010), https:// digitalcommons.unomaha.edu/jrf/vol14/iss1/23.

7 James Aston ve John Walliss, “The (Un)Christian Road Warrior: The Crisis of Religious Representation in The Book of Eli (2010)," Journal of Religion \& Film 15, sy 1 (2011), https:// digitalcommons.unomaha.edu/jrf/vol15/iss1/1.

8 Seth Walker, “'It's not a F****** Book, It's a Weapon!': Authority, Power, and Mediation in The Book of Eli," Journal of Religion \& Film 20, sy 3 (02 Ekim 2016), https://digitalcommons. unomaha.edu/jrf/vol20/iss3/29. 
göstermeye yönelik niteliksel film analizi metoduyla ${ }^{9}$ ve objektif bir bakış açısıyla incelenecektir. Çalışmamızın başlıklandırma ve işlenişinde ise tümdengelim yöntemi izlenecektir. Bu çerçevede öncelikle dinlerde kutsal kitaplar ve değeri hakkında, ardından Hıristiyanlıkta kutsal kitap anlayışı ve sonrasında The Book of Eli filmi hakkında genel bir bilgi verilecek, daha sonra da filmdeki dinî öğeler, mesajlar ve kutsal kitap vurgusu ele alınacaktır.

\section{Dinlerde Kutsal Kitaplar ve Değeri}

Dinlerin nerdeyse tümünde, değerli, kutsal olarak kabul edilen, içerisinde çoğu zaman ideal bir müntesipten beklenen ahlakî kuralların, o inançla ilgili öğretilerin ve çeşitli uygulamaların bulunduğu metinler veya kitaplar mevcuttur. Ancak bu metinler aynı değere ve büyüklüğe sahip olmadığı gibi, hepsi için aynı içerik sınıflandırması yapmak da mümkün değildir.

Kutsal kitapların, hemen hemen hepsinin, içinden bazı pasajların bireysel ve/ veya toplu ibadetlerde, özellikle de mabetlerde yapılan ayin ve kutlamalarda okunmasının bu ritüellerin en önemli parçasını teşkil ettiği ifade edilebilir. ${ }^{10}$

Dinlerin kendi içindeki mezheplerin/yorumların kutsal metin anlayışı farklılık gösterebilmektedir. Bunlar arasında ilgi çekici bir örnek Japon Budizmidir. Japon Budizmi içerisinde önemli yer tutan Niçiren Budizmi ve Hinduizm'in Şivacılık ile Vişnuculuk mezheplerinde olduğu gibi dinlerin içindeki bazı mezhepler, kutsal metin külliyatından sadece bir kısmını esas kabul ederken diğerlerini kutsallık açısından aynı ölçüde önemsememektedir. ${ }^{11}$ Yahudilikteki Talmut ve Hinduizm'deki Smriti türü eserlerde olduğu gibi birçok dinde kutsal kitapların yorumu niteliğindeki metinlere de neredeyse kutsal kitaplar kadar değer verilmekte; hatta bunlardan bazıları sosyal yaşamda asıl dinî metinlerden daha etkili olarak kabul edilmektedir. ${ }^{12}$

Sihlerin ve Müslümanların uygulamalarında olduğu gibi bazı dinlerde kutsal kitabın hatmi törenlerine önem verilmekte; merasim sonrası gelenlere ikramda bulunulmaktadır. Yine Sihler, Müslümanlar ve Yahudilerin çoğunluğunun kabul ettiği gibi bazı dinlerde, metinlerdeki yazılar, kutsallığından dolayı yüksekçe yere

9 Metod ve kullanımıyla ilgili bkz.Müge Karahan, "Filmler Yalan Söyler mi?,” Sabitfikir.com, erişim 17 Mart 2020, http://www.sabitfikir.com/elestiri/filmler-yalan-soyler-mi\&amp\%3Breferer=81590.

10 Ahmet Güç, Dinlerde Mabed ve İbadet (İstanbul: Ensar Neşriyat, 2005).

11 Aysel Okudan, "Lotus Sutra ve Budist Kutsal Metinleri Arasındaki Yeri ve Önemi” (Yüksek Lisans Tezi, Ankara Üniversitesi, 2017); Korhan Kaya, Lotus Sutra (İstanbul: Sujala Yayınc1lık, 2018); Süleyman Turan ve Emine Battal, Dünya Dinlerinde Kutsal Metinler, 2. bs (STS Yayınlar1, 2018).

12 Ali İhsan Yitik, Doğu Dinleri (İstanbul: İsam / İslam Araştırmaları Merkezi, 2014), 27; Mehmet Alparslan Küçük, Kutsal Kitap Anlayışı Yahudilik, Hiristiyanlık ve İslam Örneği, 2. bs (Berikan Yayınevi, 2016). 
konulmakta, belden aşağıya indirilmemeye gayret edilmekte ve özel bazı nüshaları süslenerek muhafaza edilmektedir. ${ }^{13}$

Hıristiyanlık ve Sihizm kutsal kitapları örneğinde olduğu gibi bazı kitapların, başka dinlere ait kutsal metinlere veya diğer dinlerden kişilerin sözlerine yer verdiği görülmektedir. ${ }^{14}$ Şintoizm'in kutsal kitapları Kociki ve Nihongi örneğindeki gibi, bazı dinlerin kutsal/değerli kitapları Tanrı'dan gelen vahiy mahsulü olarak kabul edilmemekte; halk arasında, yaratılış ve çeşitli ahlaki konulara dair yüzyıllardır dolaşan hikayelerin toplandığı metinler halinde organize edildikleri görülmektedir. ${ }^{15}$ Budizm ve Konfüçyanizm'in dinî metinlerinde olduğu gibi bazı kutsal kitap külliyatının içinde bu dinlerin kurucularına ait sözler olduğu gibi bu şahıslardan önce ve sonra yaşamış kişilerin sözlerine de yer verilmektedir. ${ }^{16}$

Vahiy kaynaklı dinler olarak kabul edilmeleri ve bünyelerinde bulunan bazı benzerlikler yüzünden bir takım araştırmacılarca "İbrahimî, semitik, ilahî, semavî dinler" gibi nitelendirmelerle sınıflandırma yapılarak diğer dinlerden ayrı bir kategoride ele alınsa da İslam, Hıristiyanlık ve Yahudiliğin, kutsal kitap anlayışı da aynı değildir. Bu üç dinin de kutsal saydığı temel bir kitap olmakla birlikte her bir dinde bu kitabın yeri ve değeri farklıdır. Dahası, Yahudilik ve Hıristiyanlıkta olduğu gibi bu kitapların tümünün vahiy ürünü olup olmadığını tartışan mezhepler de mevcuttur. İslam'ın kutsal kitabı Kur'an'ın, diğer iki dinin kutsal kitabından farklı olarak, vahyedilmesi esnasında bu dinin peygamberi Hz. Muhammed'in (sav) kendisine gelen vahiyleri vakit kaybetmeden vahiy kâtiplerine okumasıly onlar tarafından yazıya geçirildiği bilinmektedir. Yahudilik ve Hıristiyanlıkta ise süreç daha farklıdır; Yahudi inancına göre kutsal kitap, belirli bir süre sözlü olarak nakledildikten sonra yazıya geçirilmiştir. Hıristiyanlara göre Rab olarak teslisin bir unsuru sayılan Mesih İsa'nın bizzat kendisi kelamdır/vahiydir ve insanlar arasında yaşarken başka bir kitap bırakmamıştır. Ancak İsa Mesih, çarmıh olayından üç

13 Şinasi Gündüz, "Sih Dini," içinde Yaşayan Dünya Dinleri, ed. Şinasi Gündüz (Ankara: Diyanet İşleri Başkanlığı, 2007), 379; Cemil Kutlutürk, "Hint Dinleri," içinde Dünya Dinleri, ed. Şinasi Gündüz (İstanbul: Milel \& Nihal, 2019), 226; Cengiz Batuk, "Sihizm," içinde Dinler Tarihi I-II (İstanbul: Lisans Yayınc1lık, 2018), 292.

14 Yitik, Doğu Dinleri, 176; Batuk, "Sihizm," 290-91; Mehmet Aydın, "Hıristiyanlık (Kutsal Metinler ve Dini Literatür)," içinde Diyanet İslam Ansiklopedisi (İstanbul: Türkiye Diyanet Vakf1 Yayınlar1, 1998), 340.

15 Okan Haluk Akbay, Kojiki: Japon Mitolojisine Bir Yolculuk (Konya: Çizgi Kitabevi, 2014); Halil İbrahim Şenavcu, "Japon Dinleri," içinde Dünya Dinleri, ed. Şinasi Gündüz (İstanbul: Milel \& Nihal, 2019), 263-64.

16 Günay Tümer, "Budizm," içinde Diyanet İslam Ansiklopedisi (İstanbul: Türkiye Diyanet Vakfi Yayınlar1, 1992), 355-56; Edward J. Thomas, The History of Buddhist Thought, 7. bs (London: Routledge, 1971), 261-92; Cuma Özkan, “Çin Dinleri," içinde Dünya Dinleri, ed. Şinasi Gündüz (İstanbul: Milel \& Nihal, 2019), 237-39. 
gün sonra havarilerini misyonunu yaymakla görevlendirip göklere çekilmesini müteakiben bir süre sonra onun hayatı ve mesajının takipçileri tarafindan Kutsal Ruh'un gözetiminde/ilhamla yazıldığına inanılmaktadır. ${ }^{17}$

\section{Hıristiyanlıkta Kutsal Kitap Anlayışı}

Hıristiyanlıkta "Eski Antlaşma/Ahit" ve "Yeni Antlaşma/Ahit" olarak iki parçadan oluşan, Türkçeye "Kutsal Kitap" (Bible) olarak çevrilen (Kitab-1 Mukaddes diye de bilinen) bir kutsal metin anlayışı vardır. Bu kitabın içindeki ilk metinlerin (Eski Antlaşma), Tanrı'nın eskiden insanlarla (özelde Yahudilerle) olan antlaşmasını, onlara olan talimatlarını içerdiği ve Tanrı'nın sözleri olduğu için de kutsal olarak nitelendirilmesi gerektiği ifade edilmektedir. Yaratılış hadisesi, peygamber kıssaları gibi hususlar aynen kabul edilirken, emir ve yasaklar gibi hususların Tanrı'nın insanlıkla sonradan yaptı̆̆g Yeni Antlaşma ile neshedildiği ve yenilendiği/ güncelleştirildiği iddia edilmektedir. ${ }^{18}$

Hıristiyanlara göre asıl uyulması gereken Yeni Antlaşmadır. Yeni Antlaşma ise pek çok kitaptan/bölümden müteşekkildir. Bu bölümlerden ilk dört tanesi İnciller (Gospels) olarak isimlendirilmektedir ki bunlar sırasıyla Matta, Markos, Luka ve Yuhanna tarafindan İsa'nın (a.s) hayatı ve mesajıyla ilgili yine Tanrı'nın (Kutsal Ruh) ilhamıyla yazıldığı tahmin edilen metinlerdir. Sonrasında Yeni Antlaşma'nın içerisinde Luka tarafindan yazıldığı tahmin edilen, İsa'nın ilk takipçilerinin, mesajı yayma gayretlerinin anlatıldığı Elçilerin İşleri bölümü, ondan sonra İsa'nın ilk takipçileri tarafından yazıldığına inanılan 21 mektup, ardından ise geleceğe dair olayların Yuhanna'nın İsa' dan vahiy alarak sembollerle aktardığına inanılan Vahiy bölümü yer almaktadır. Kutsal metin külliyatına dâhil edilmesi kararlaştırılan bu kitaplar "kanonik" (sahih) olarak adlandırılmaktadır. Bir kısım o dereceye ulaşamadığı için dâhil edilmeyenlere ise "apokrif" (sahih olmayan) denilmektedir. Yeni Antlaşma'nın ilk üç bölümü (Matta, Markos ve Luka) ise birbirine benzediğinden dolay1 "sinoptik" (benzer) İnciller olarak isimlendirilmektedir. ${ }^{19}$

17 Aydın, "Hıristiyanlık (Kutsal Metinler ve Dini Literatür)"; Harun Dündar Karahan, "Hıristiyan Mezheplerinde Vahiy Anlayış1," Bozok Üniversitesi İlahiyat Fakültesi Dergisi 13, sy 13 (28 Haziran 2018): 287-308; Küçük, Kutsal Kitap Anlayışı; Baki Adam, Yahudi Kaynaklarına Göre Tevrat, 2. Basım (İstanbul: Pınar Yayınları, 2002); Abdurrahman Küçük, Günay Tümer, ve Mehmet Alparslan Küçük, Dinler Tarihi (Ankara: Berikan Yayınevi, 2009), 305-16, 373-83, 593-95.

18 Mahmut Aydın, "Hıristiyanlık (Tarihsel Gelişimi, Temel Kaynakları ve Öğretileri)," içinde Yaşayan Dünya Dinleri, ed. Şinasi Gündüz (Ankara: Diyanet İşleri Başkanlığı, 2007), 78; Küçük, Kutsal Kitap Anlayışı; Aydın, "Hıristiyanlık (Kutsal Metinler ve Dini Literatür)," 340.

19 Aydın, "Hıristiyanlık (Kutsal Metinler ve Dini Literatür)," 340-41; Maurice Bucaille, Müsbet Ilim Yönünden Tevrat Inciller ve Kur'an, çev. Mehmet Ali Sönmez, 7. bs (Ankara: Diyanet İşleri Başkanlığı, 2001), 85-140; Aydın, "Hıristiyanlık (Tarihsel Gelişimi, Temel Kaynakları ve Öğretileri),” 78-85; Ali Erbaş, Hristiyanlık (İstanbul: İnsan Yayınları, 2004), 77-92. 
Kutsal Kitap'a bakış hususunda Hıristiyanlar arasında bazı farklılıklar vardır. Kutsal Kitap'1 tek otorite kabul eden Protestanlara karşı Katolikler, bazı zamanlarda özellikle Eski Anlaşma'nın bölümlerinin, çeşitli zamanlarda farklı kişiler tarafından değişik dokümanlardan derlendiğinden hareketle bazı hataların, sorunların olduğunu iddia edenlere destek olmuşlardır. Batıda zaman zaman Kutsal Kitap kritikleri/ eleştirileri yapılmış ve metinler içindeki hatalar ortaya konulmuştur. ${ }^{20} \mathrm{Bu}$ eleştirilere Müslüman ilim adamları ve araştırmacılar da katılarak konuyla ilgili eserler vermişlerdir. ${ }^{21}$

Müslümanlara göre Hz. İsa da, ilk peygamber Hz. Âdem'den Hz. Muhammed'e kadar devam eden peygamber silsilesinden bir elçidir. O'na İncil vahyedilmiş, ancak ona vahyedilen bu İncil günümüze kadar gelmemiştir. Hıristiyan kutsal metinlerinden mevcut İnciller olarak nitelendirilen bölümlerde Allah'a ve Hz. İsa'ya ait sözler de olabilir, fakat bunların tamamen Allah ya da Hz. İsa'ya ait olduğu söylenmemektedir.

\section{The Book of Eli Filminin Künyesi ve Konusu}

The Book of Eli, Türkçe'ye “Tanrı'nın Kitabı” olarak çevrilen, başrolünde Denzel Washington'in Gary Oldman, Mila Kunis, Ray Stevenson gibi ünlülerle oynadığı, ABD- New Mexico yapımı, aksiyon, gerilim, bilim-kurgu, macera türü bir filmdir. Senaryosu Gary Whitta tarafindan yazılmış olan filmin yönetmenliğini ise Hughes kardeşler (The Hughes Brothers) diye meşhur olan Albert Hughes ve Allen Hughes yapmıştır. Dağıtımı Warner Bros. Pictures tarafından gerçekleştirilen filmin yapımcılığını ise Joel Silver, Denzel Washington, Andrew A. Kosove, Broderick Johnson, David Valdes’ten oluşan kalabalık bir ekip üstlenmiştir. 2010 yapımı olan film, 118 dakika olup 6.9 (17.03.2020 tarihi itibariyle, 281.692 kullanıcinın oyuyla) IMDb puanına sahiptir. ${ }^{22}$

Film, dünyanın büyük bir bölümünü etkileyen oldukça kapsamlı bir patlama sonucunda Tanrı tarafından seçilmiş Eli isimli bir kişinin sağ kalan insanları kurtarmak için, son versiyonu kalan değerli bir kitabı (Kitab-1 Mukaddes/Bible-

20 Baki Adam, "Yahudilik: Tarihsel Gelişimi, İnanç Esasları ve İbadetleri," içinde Yaşayan Dünya Dinleri, ed. Şinasi Gündüz (Ankara: Diyanet İşleri Başkanlığı, 2007), 223-26; Benedictus Spinoza, Teolojik-Politik İnceleme, çev. Cemal Bâli Akal ve Reyda Ergün, 4. Baskı (Ankara: Dost Kitabevi, 2016); Bucaille, Müsbet İlim Yönünden Tevrat İnciller ve Kur'an.

21 Şaban Kuzgun, Dört İncil Farklılıkları ve Çelişkileri, 2. bs (İstanbul: Fazilet Neşriyat, 2008); Mehmet Aydın, Müslümanların Hristiyanlara Karşı Yazdiğı Reddiyeler ve Tartışma Konuları (Ankara: Türkiye Diyanet Vakfı Yayınları, 1998), 145-84; Sabri Çap, Goldziher Öncesi Oryantalizm ve Hadis (Ankara: İlahiyat Yayınları, 2019), 124-26. 
The King James Version) koruma mücadelesi ve bu esnada yaşadığı maceraları, bu kitabı ele geçirenlerin dünyayı nasıl kolay yöneteceği vurgusuyla anlatır.

Filmin İngilizce orijinal afişlerindeki "The Book of Eli” isminin Türkçesi "Eli’nin Kitabı” olması gerekirken “Tanrı'nın Kitabı” olarak çevrilmiştir. Filmde odak nokta, Eli adındaki bir kahramanın korumaya çalıştığı bir kitap olmakla birlikte, aynı zamanda bu kişinin 'Tanrı adına hareket eden seçilmiş şahıs' olduğu, çeşitli sahnelerde vurgulanmaktadır. Dolayısıyla amacı yansıtmak için özellikle tercih edildiği düşünülen başlığın bu çevirisi Hıristiyan inancı ve verilmek istenen mesaja uygun olarak seçilmiştir. Çünkü film başlıklarının çevirilerinde, filmlerin vermek istedikleri mesajlar çerçevesinde tercihlerde bulunulması, yaygın kullanılan yöntemlerden biri olarak bilinmektedir. ${ }^{23}$

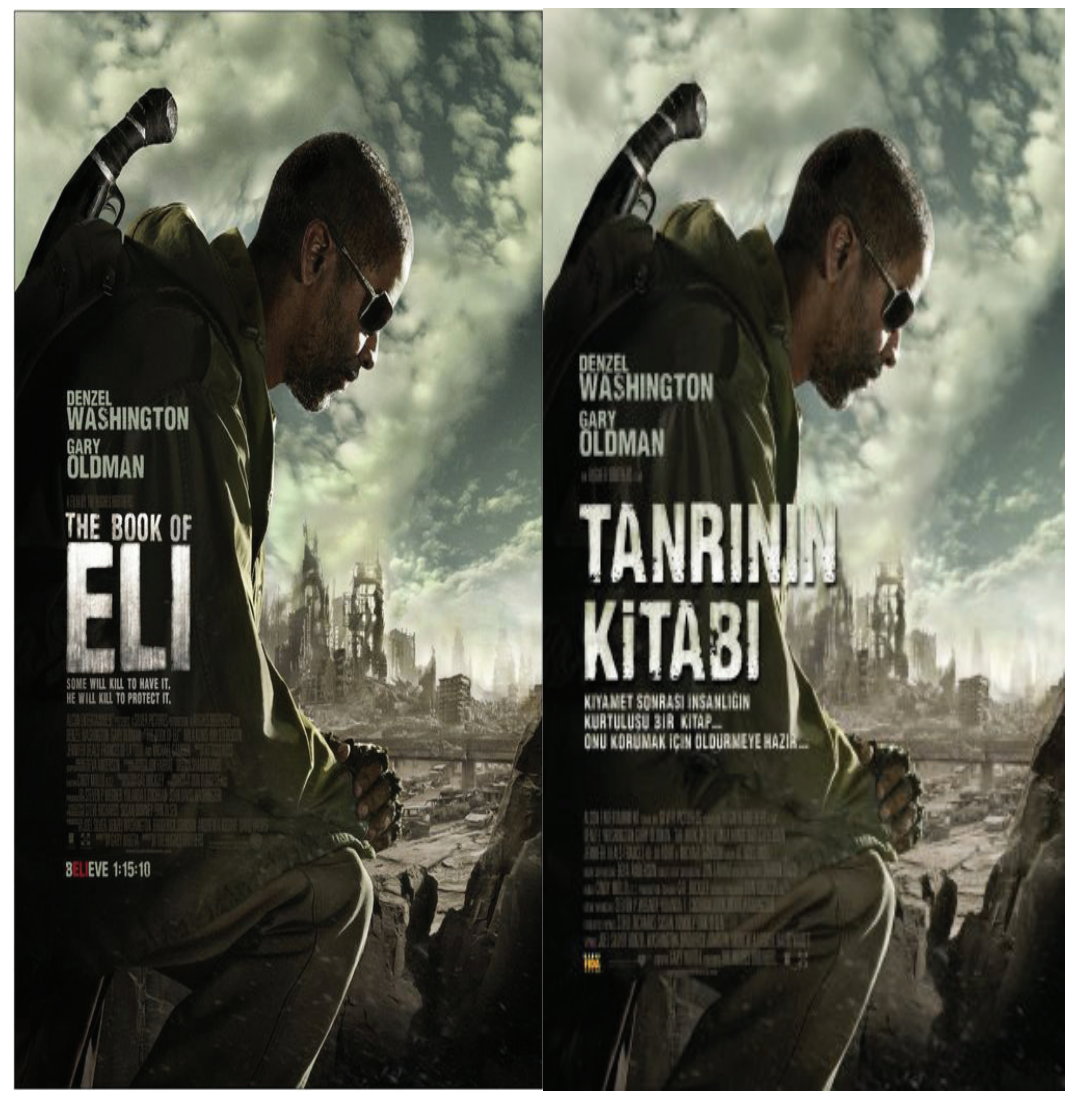

Şekil 1. "The Book of Eli” Filmi İngilizce ve Türkçe Afişleri

23 Gülhanım Ünsal, "Film Başlıklarının Çevirisi Üzerine Gözlemler,” Avrasya Sosyal ve Ekonomi Araştırmaları Dergisi 5, sy 5 (31 Mayıs 2018): 77-92. 


\section{Filmdeki Dinî Öğeler, Mesajlar ve Kutsal Kitap Vurgusu}

The Book of Eli filminin afişlerinde ve tanıtım posterlerinde yer alan "Belive" (İman et) ifadesi dinî mesaj olarak göze çarpmaktadır. Yine filmin posterlerinden birinde "Religion is power (Din, güçtür.)." ifadesi, film boyunca vurgulanan önemli bir dinî mesajdır.

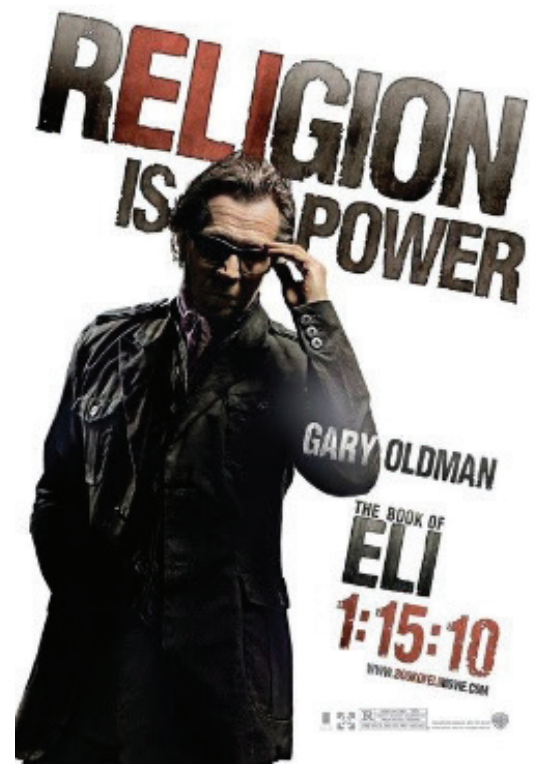

Şekil 2. "Din, güçtür” Yazılı “The Book of Eli” Film Afişi

Eli (Denzel Washington), küçük bir kasabanın zorba yöneticisi Carnegie (Gary Oldman) tarafindan zorunlu misafir edilirken kameraya duvarda asılı olarak yansıyan büyük savaş öncesine ait eski takvim (37:40), 2024 yılını göstermektedir. Ancak savaşın üzerinden $30 \mathrm{kış/yıl} \mathrm{(41:30)} \mathrm{geçtiğine} \mathrm{göre} \mathrm{muhtemelen} \mathrm{bu} \mathrm{olayların}$ yaşandığı zamanlar olarak 2054 y1llarından bahsedildiği, apokaliptik ${ }^{24}$ ve postapokaliptik $^{25}$ öğeler taşıdığ 1 ifade edilmek istenmektedir. ${ }^{26}$

24 Apokaliptik, "açıklama, ifşa, vahiy" gibi anlamlara gelmekle birlikte, "dünyanın sonuna, kıyamete yakın olacak olayların bilgisi”" anlamında kullanılmıştır. Şinasi Gündüz, Din ve İnanç Sözlü̆̈̈̈, 2. bs (İstanbul: Vadi Yayınları, 2017), 46.

25 Post-apokaliptik, "kıyamet sonrası" ya da "dünyayı tarumar edecek büyük bir savaş ve/veya patlama sonrası" anlamında kullanılan bir kavramdır. Post-apokaliptik temalar, Amerikan bilimkurgu sinemasında oldukça önemli yer tutmaktadır. Bkz. Mikail Boz ve Dilek Takımcı, “Amerikan Post-Apokaliptik Bilimkurgu Sinemasında Kıyamet İdeolojisi (1924-2000)," Akdeniz Üniversitesi İletişim Fakültesi Dergisi, sy 31 (30 Haziran 2019): 377-403.

26 Ayrıca bkz. John Petrakis, "The Book of Eli," The Christian Century, 2010, 43; Walker, "It's not a F****** Book, It's a Weapon!”; Russ Breimeier, "The Book of Eli,” ChristianityToday. com, 15 Ocak 2010, https://www.christianitytoday.com/ct/2010/januaryweb-only/bookofeli. html; Porter, "The Book of Eli," 1. 
Filmin, gelecekte insanlığın çoğunu etkileyecek büyük bir savaşta yaşanan patlama sonrasına dair görüntülerle başlaması, Hıristiyan inancı hakkında malumatı olanların hemen aklına geleceği üzere, daha en baştan dinî bir mesaj verileceğine dair bir giriş sunmaktadır. Çünkü Hıristiyan kutsal kitabının içerisindeki Yeni Ahit'in Vahiy Bölümünde yer alan bir pasajda, ${ }^{27}$ kıyamet öncesi Mesih İsa yeryüzüne tekrar inmeden önce Armagedon ${ }^{28}$ denilen yerde, dünyadaki tüm kralların katılacağı iyilerle kötüler arasında yapılacak çok büyük bir savaşın neticesinde dünyada önemli olayların gerçekleşeceğinden bahsedilmektedir. Dolayısıyla film, seyirciye ilk sahnelerden itibaren Hıristiyan itikadında var olan kıyamet öncesi yaşanacaklar (eskatoloji) ${ }^{29} \mathrm{ve} \mathrm{Hz}$. İsa'nın dünyaya tekrar geleceği inancın $1^{30}$ da hatırlatmaktadır.

Her ne kadar kendisini "Hiç kimse!" olarak tanıtsa da (33:13) kitabı korumak ve hedefine ulaştırmakla görevli Eli, filmin bir sahnesinde (31:44), Kitab-1 Mukaddes’ten (Yaratılış 3/17-19) “...Toprak senin yüzünden lanetlendi” “... Toprak sana diken ve çalı verecek, ... Çünkü topraksin, topraktan yaratıldın ve yine topră̆a döneceksin." pasajını kendisine saldırmaya hazırlanan kişilere okur ve ardından kalabalık saldırgan grubun tüm üyelerini birkaç dakikada her zaman yanında taşıdığı k1lıç benzeri aletle yere serer. Bunun gibi filmin pek çok yerinde kalabalıklarla dögüuşünde çok kolay bir şekilde başarılı olmaktadır. Ayrıca çete

27 Vahiy Bölümü’nde (özellikle de 16/14-21) dünyada kötülükler arttığında Armagedon denilen bir yerde yapılacak büyük bir savaştan (Armagedon Savaşı) şöyle bahsedilmektedir: “....Her Şeye Gücü Yeten Tanrı'nın büyük gününde olacak savaş için bütün dünyanın krallarını toplamaya gidiyorlar. "Işste hırsız gibi geliyorum! Çıplak dolaşmamak ve utanç içinde kalmamak için uyanık durup giysilerini üstünde bulundurana ne mutlu!' Ü̧̧ kötü ruh, kralları İbranice Armagedon denilen yere topladılar. Yedinci melek tasını havaya boşalttı. Tapınaktaki tahttan yükselen gür bir ses, "Tamam!" dedi. O anda şimşekler çakt, uğultular, gök gürlemeleri işitildi. Öyle büyük bir deprem oldu ki, yeryüzünde insan oldu olalı bu kadar büyük bir deprem olmamışt. Büyük kent üçe bölündü. Ulusların kentleri yerle bir oldu. Tanrı büyük Babil'i anımsadı, ona ateşli gazabının şarabını içeren kâseyi verdi. Bütün adalar ortadan kalktı, dağlar yok oldu. Insanların üzerine gökten tanesi yaklaşık kurk kilo ă̆ırlı̆̆ında iri dolu yağdl. Dolu belası öyle korkunçtu ki, insanlar bu yüzden Tanrı'ya küfrettiler." Benzer sahneler için bkz. Hezekiel, 38-39. Çalışma boyunca yapılan Kitab-1 Mukaddes alıntıları için bkz. Kutsal Kitap (İstanbul: Kitab-1 Mukaddes Şirketi, 2001).

28 Armagedon kavramının İbranice, Har (dağ) ve Megiddo ifadelerinin bir araya gelmesinden oluştuğu ve Megido Dağı anlamına geldiği ifade edilir. John Bowker, The Concise Oxford Dictionary of World Religions (Oxford: Oxford University Press, 2000), 53; Gündüz, Din ve Inanç Sözlüğü, 51. Armagedon hakkında ayrıntılı bilgi için bkz. Mustafa Bıyı, Armagedon ve Tanrı Krallığı (Ankara: Aziz Andaç Yayınları, 2008); Grace Hallsell, Tanrlyı Kıyamete Zorlamak: Armagedon, Hıristiyan Kıyametçiliği ve İsrail, çev. Mustafa Acar ve Hüsnü Özmen, 2. bs (Ankara: Kim Yayınları, 2003).

29 Mustafa Bıyık, "Hıristiyan Eskatolojisinde Dünyanın Sonu Kehanetleri," Marife Dini Araştırmalar Dergisi 7, sy 2 (01 Ekim 2007): 163-88; Muhsin Akbaş, "Yahudi ve Hiristiyan Düşüncesinde Ölüm Sonrası Hayat ve Diriliş İnancının Dini ve Teolojik Temelleri,” Dokuz Eylül Üniversitesi Illahiyat Fakültesi Dergisi, sy 41 (2002): 37-60.

30 Sami Baybal, İbrahimî Dinlerde Mesih'in Dönüşü (Konya: Yediveren Kitap, 2002); Ekrem Sarıkçıŏlu, Dinlerde Mehdi Tasavvurları (Samsun: Sidre Yayınları, 1997). 
üyelerinden birinin Eli hakkında "Sanki bir şey, onu koruyor gibi. Sanki hiç zarar görmeyecek gibi." (01:04:08) şeklinde bir cümle kurmuştur. Bu sahnelerle de Eli'nin sıradan birisi olmadığı, Tanrı'nın mesajıyla bağlantılı bir şahsiyet olduğu açıkça işlenmektedir.

Filmdeki bir sahnede (01:05:46-01:09:48) Eli ile Solara (Mila Kunis) arasında şöyle bir diyalog geçmektedir:

"Solara: Gerçekten de her gün aynı kitabı mı okuyorsun?

Eli: Hiç aksatmadan...

Solara: Bana da okur musun? Lütfen!

Eli: "Tanrı çobanımdır, benim eksiğim olmaz. Beni taze çayırlarda yatırır, sakin sular boyunca yürütür, ruhumu tazeler. Kendi ismi uğrunda beni doğruluk yollarında güder. Ölüm gölgesi vadisinde gezsem bile, şeytandan korkmam. Çünkü Tanrı benimle. (Mezmurlar 23/1-4)

Solara: Çok güzelmiş.

Eli: Hoşuna gitti mi?

Solara: Sen mi yazdin?

Eli: Evet!

Solara: Gerçekten mi?

Eli: Hah! Hayır, hayır, hayır! Bu, senden ve benden çok daha uzun zamandır burada, orası kesin!

Solara: Bu, siradan bir kitap değil derken ne demek istiyordun?

Eli: Bu tek!

Solara: Gerçekten mi?

Eli: Savaştan sonra insanlar ateşin yok etmediklerini bulup yok etmeyi kendilerine görev edindi. Bazıları, savaşın zaten bu yüzden çıktığını söylüyordu. Her neyse geriye sadece bu kaldı.

Solara: Eline nasıl geçti?

Eli: Savaşın, gökyüzünde bir delik açtığını söylüyorlar. Bunu duymuşsundur.

Solara: Evet

Eli: Gökyüzünde bir delik açmış, güneş oradan inmiş ve her şeyi yakmış, her şeyi ve herkesi. Böyle bir deliğe ya da yer altına saklandıysan şanslıydın. Çünkü çoğu insan şanslı değildi. Ve bir yıldan sonra dışarı çıkıp ne yapacă̆ını bilemeden etrafta öylece dolaşıyorduk ve hayatta kalacak bir yer arıyorduk. Günün birinde bir ses duydum. Açıklaması zor ama sanki o ses, içimden geliyor gibiydi. Ama seni duyduğum gibi net duyuyordum.

Solara: Ses ne diyordu?

Eli: Beni çağırdı. Kitabı bulduğum yere götürdü. Kitap orada gömülüydü ve ses, kitabı batıya götürmemi söyledi. Bana, yolumun önümde serili olduğunu ve beni kitabın güvende olacă̆ yere götüreceğini söyledi. Her türlü tehlikeye karşı korunduğumu söyledi. O günden beri de yürüyorum.

Solara: Sen de duyduğun bir ses bunları yap dedi diye yaptın!

Eli: Evet öyle! Ne duyduğumu biliyorum. Ne duyduğumu iyi biliyorum ve yardım olmadan bunu başaramazdım, bunu da biliyorum." 
Yine filmin çeşitli sahnelerinde (34:51 ve 1:18:34) Eli'nin bazı sesler duyduğundan ve olacak olaylara dair bazı şeyler söylendiğinden bahsedilmesi yukarıdaki diyalog ile birlikte değerlendirildiğinde, onun kendi başına hareket eden birisi olmadığ 1 , dünyayı tarumar edecek büyük bir din savaşının (Armagedon Savaşı) ardından Tanrı tarafından bazı bilgilerin ona verilerek yönlendirilmesi de aynı şekilde onun seçilmiş bir elçi olduğunu göstermektedir. ${ }^{31}$

Film süresince Tanrı'nın her zaman her şartta koruduğu bir elçi motifi işlenmiştir. Hıristiyanlıkta bu, bilinmeyen, yabancı bir şey değildir. Hıristiyanlığa göre gerek peygamberler gerekse de Tanrı'nın oğlu/sözü kabul edilen ve yeryüzüne insanlığı günahtan kurtarmak için Tanrı tarafından gönderildiği kabul edilen Mesih İsa inancına benzer bir imaj, başrol oyuncusu vasıtasıyla işlenmiştir. Çünkü filmin pek çok yerinde Kutsal Kitap'ın koruyucusu olan Eli'ye, defalarca saldırı düzenlenmesine rağmen bunlardan kurtulmuş, silahla ateş edilmesine karşın ona bir şey olmamış ve kendisinin bazı sesler duyduğunu ifade etmiş olması, onun Tanrı tarafindan seçilip yönlendirildiği mesajını vermektedir.

Eli'nin, yiyecek içecek sıkıntısı çekilmesinden dolayı kimsenin bunları paylaşmadığı zamanlarda yemeklerini insanlarla ve hatta hayvanlarla paylaştığının gösterildiği sahneler (08:51 ve 43:44) ile filmin iki karesinde (44:09 ve 45:59) yemeğe başlamadan önce Hıristiyan usulü yemek duasının yapılması, din ve ahlakın bir örnek şahsiyet/elçi vasıtasıyla uygulanarak gösterilmesi anlamında önemli dinî öğeler olarak göze çarpmaktadır. ${ }^{32}$

Filmde ele geçirilmek için peşinde sürekli koşulan kitap (Kutsal Kitap) için Carnegie'nin: "O bir silah. Kalpleri ve zayıflarla çaresizlerin zihinlerini hedef alan bir silah. Bize insanlar üzerinde tam kontrol verecek. Lanet bir kasabadan daha fazlasina hükmetmek istiyorsak, kitap elimizde olmal. Her yerden insanlar gelecek ve söylediklerim kitabın içindense dediklerimi yapacaklar. Bu daha önce oldu ve yine olacak. Lazım olan tek şey o kitap." sözü oldukça iyi özetlemektedir filmi. Filmde geçen bu ifadeler insanın aklına Karl Marx'ın "Din, afyondur." ifadesini getirmektedir. Bu film Porter'in değindiği üzere, "dinin olumlu ya da olumsuz kullanımıyla insanları nasıl yönlendirebileceğini” vurgulamaktadır. ${ }^{33}$

Filmde Eli'nin kitap için “Niçin onu istiyorsun?” sorusuna karşıllık Carnegie’nin: "Onunla büyüdüm, gücünü biliyorum. Sen de okuduysan sen de biliyorsundur.

31 Benzer bir bakış açısı için bkz. Porter, "The Book of Eli," 1.

32 Benzer tespitler için bkz. Aston ve Walliss, "The (Un)Christian Road Warrior," 4-5.

33 Ayrıca bkz. Porter, "The Book of Eli," 1-3. Bu fikrin gerçeği tam olarak yansıtmadığını, çünkü dinin belirsiz, müphem yönlerini de gözden kaçırmadan değerlendirme yapmak gerektiğini ifade edenler de olmuştur. Bkz. Aston ve Walliss, "The (Un)Christian Road Warrior," 1-4. 
Bu yüzden savaştan sonra hepsini yaktılar. Hayatta kalmak bile inancin eseri. Bu kasabay kurmak daha büyük bir inancın eseri ama insanlar anlamıyor..." ifadeleri de bu kitabın ne kadar değerli olduğuyla ilgili verilen bir diğer mesajdır.

"İnanırsan her zaman üstün gelecek olan sensin!”, “İman et kurtul!”, “Tanrı’nın sözüne/kitabına/mesajına hizmet eden, her zaman hedefine ulaşır, bazı sıkıntılar yaşasa da!" gibi dinî mesaj ve vurgular filmin genelinde yoğun olarak işlenmektedir.

Filmde Eli'nin koruduğu kitabın kötü adamlar tarafından ele geçirilmesi sonucu, bu kitabın görme engellilerim kullandığı kabartmalı, altı noktalı Braille alfabesiyle yazılı olduğunun gösterilmesi, Eli'nin normalde görme engelli olmasına rağmen, onu koruyan Tanrı'nın inayetiyle nasıl görür hale geldiği mesajı vermektedir. ${ }^{34}$

Filmin sonunda kütüphaneye kayıp İncil yerleștirilirken gösterilen sahnede daha önceden Tevrat'ın ve Kur'an'ın oradaki rafta mevcut olduğu göze çarpmaktadır. Ancak baştan beri filmin konusu akla getirildiğinde, "Bu kitaplar var olsa da, hepsi toplansa bir İncil etmez!" gibi bir vurgu kendini hissettirmektedir.

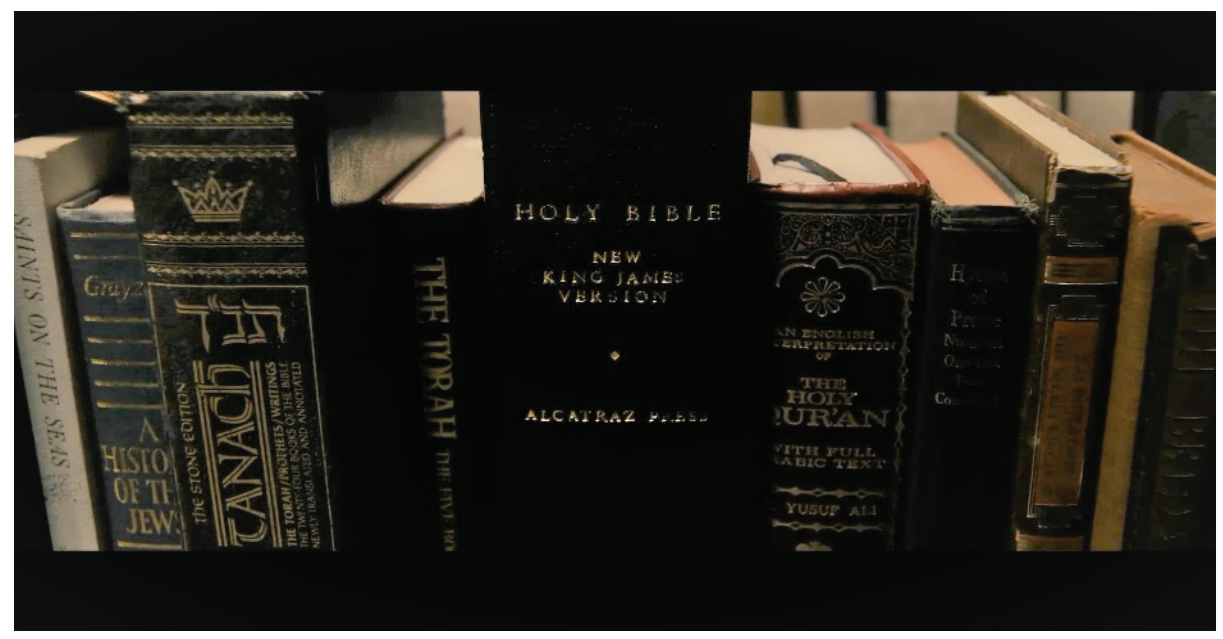

Şekil 3. Kitab-1 Mukaddes, Kütüphanedeki Rafına Yerleştirilirken

Film hakkında yorumların bulunduğu Türkçe internet sitelerine bakıldığında, verilmek istenen dinî mesajların çoğu kişi tarafından önemsenmediği veya anlaşılmadığı göze çarpmaktadır. Bu sitelerin çoğunda yorumların az bir kısmı

34 Porter, "The Book of Eli," 3. Film boyunca Eli’nin, gözleri görmeyen biri olup olmadığı da net olarak anlaşılmamaktadır. Bu konu hakkındaki tartışma için bkz. Walker, "It's not a $\mathrm{F}^{* * * * * * *}$ Book, It's a Weapon!',” 3. 
(en fazla \% 20 kadarı) filmin bünyesindeki dinî içeriği önemsemektedir. ${ }^{35}$ Dinî mesajları tespit eden yorumların ise oldukça isabetli olduğunu ifade etmek gerekir. ${ }^{36}$ IMDb gibi İngilizce sitelerde ise bu durumun aksine, yorumların çoğunluğunda dinî öğelerden ve bunların nasıl işlendiğinden bahsedilmektedir. ${ }^{37}$ Film eleştirmenleri bu filmdeki dinî öğeleri ve mesajları yerli yerince tespit etmiş, bu konudaki yorum ve eleştirilerini sıralamışlardır. ${ }^{38}$

\section{Sonuç ve Değerlendirme}

Kutsal kitaplar, dinler için önemli bir konuma sahiptir. Zamanla müntesiplerde meydana gelen kutsal kitaptan uzaklaşma/soğuma davranışları bazı dindarları ve din adamlarını rahatsız eder. Ayrıca bu kişilerin "davaları uğruna" diğer inanç müntesiplerine kendi kutsal kitaplarının önemini göstermek/ispatlamak, bu vesileyle başka dinlerden kimseleri kendi inançlarına çekebilme düşüncesi de vardır. Bu durum, kendi mensuplarına kutsal kitabın değerini vurgulamak istemesiyle birleştiğinde bunu yapabilmek için yeni yöntemlerin uygulanmasını zorunlu kılar. Dolayısıyla tüm bu nedenlerden dolayı, günümüzün en kullanışlı ve kolay etki etme yöntemlerinden biri olan film insanlara yeni bir teknik sunar.

Sinema/film, tarihten bu yana eğlendirme ve güzel vakit geçirme vasitası olmasının yanı sıra gerek bilgilendirme gerekse de mesaj verme gibi çeşitli amaçlar için kullanılmıştır. Filmlerin, farklı dinlere ait bilgi vermekle birlikte o dinlerin kutsallarının önemini dinin müntesiplerine vurgulamak için de tercih edildiği görülür. Filmler vasıtasıyla dinî mesaj verenler, sadece bir dinin içindeki inananları hedef kitle olarak seçmekle kalmayabilir; aynı zamanda başka dinlerin inananlarına da bir takım dinî mesajlar vererek onları kendi dinlerine çekme düşüncesinde olabilirler.

35 “The Book of Eli (2010)," erişim 22 Ekim 2019, https://720p-izle.com/izle/altyazi/the-bookof-eli.html; "Tanrının Kitabı The Book of Eli,” erişim 22 Ekim 2019, http://www.sinematurk. com/film/28684-tanrinin-kitabi/; “Tanrının Kitabı (The Book of Eli)," Intersinema.com, erişim 02 Kasım 2019, https://www.intersinema.com/tanrinin-kitabi-filmi/.

36 “Tanrının Kitabı (2010) - The Book Of Eli,” erişim 22 Ekim 2019, https://www.sinemalar.com/ film/21844/tanrinin-kitabi; “Tanrının Kitabi,” erişim 22 Ekim 2019, http://www.beyazperde. com/filmler/film-128955/kullanici-elestirileri/en-yeniler/.

37 “The Book of Eli (2010) User Reviews," erişim 02 Kasım 2019, http://www.imdb.com/title/ tt1037705/reviews; "The Book of Eli (2010)," erişim 02 Kasım 2019, https://www.rottentomatoes. com/m/the_book_of_eli.

38 Film eleştirmenlerinin bazılarının yorum ve eleştirileri için bkz. Roger Ebert, "The Book of Eli Movie Review," erişim 02 Kasım 2019, https://www.rogerebert.com/reviews/the-book-ofeli-2010; Murat Tolga Şen, “Tanrının Kitabi : Beyazperde.com Eleştirisi,” erişim 02 Kasım 2019, http://www.beyazperde.com/filmler/film-128955/elestiriler-beyazperde/; Andrew Pulver, "Film Review: The Book of Eli," The Guardian, 14 Ocak 2010, blm. Film, https://www.theguardian. com/film/2010/jan/14/book-of-eli-film-review; Breimeier, "The Book of Eli”. 
$\mathrm{Bu}$ durum en azından kendi dinlerine karşı antipatik bakış açısını engellemeye dönük de olabilir. Film senaristleri, yapımcıları, yönetmenleri kendi inançları doğrultusunda izleyicileri olumlu yönde etkileyerek bir çeşit misyonerlik faaliyeti içinde de olabilirler. Bazen filmlerin, mevcut yapıdaki uygulamaların gerçek dinde olmadığı, sonradan halkın içine girerek yaygınlaşan hurafelerin dışarıdan nasıl algılandığını göstermek için komik/trajikomik sahnelerle bunları vurguladıkları da görülür.

Filmlerde bazen dinin kutsallarından birisi daha fazla ön plana çıkarılarak onun üzerinden mesaj verildiği de görülür. İşte bu mesajın verildiği filmlerden biri de The Book of Eli (Tanrı'nın Kitabı) filmidir. Bu filmde özellikle üstünde durulan ve verilmek istenen ana mesajın Tanrı'nın sözünün/mesajının/kitabının ilelebet yeryüzünden kaybolmayacağı, mutlaka bu mesajı taşıyacak bir elçinin bulunacağıdır. Film içeriğinden anlaşılacağı üzere, sürekli olarak, kıyamet benzeri bir zamanda büyük bir patlama sonucu üzerinde yaşayan çok az insanın kaldığı yeryüzünde hâkimiyeti ele geçirip herkesi yönetebilmek için değerli bir kitabın (Kitabı-1 Mukaddes/Bible) korunma ve ele geçirilme mücadelesi vardır. Filmde insanların böyle bir ortamda ilişkilerinin nasıl olabileceğinden, ihtiyaçlarını giderebilmek için hangi yol ve yöntemlere başvurabileceğinden de bahsedilir. Burada dahi mesaj olarak, insanların bu durumda peygambersiz ve kitapsız kaldıklarında Hıristiyanlıktaki algı çerçevesinde, insanlığın ilk yaratıldığı zamanlara döneceği, zihinlere işlenir.

Tanrı'nın kitabı filminin, kutsal kitap vurgusuyla birlikte verdiği başka yan mesajlar da vardır. Bunların en önemlileri, eskatolojik, apokaliptik adı verilen yani dünyanın sonuna dair yapılan vurgular ve insanlar içinden seçilmiş bir elçinin Tanrı tarafından her şartta korunacağı ve mesaj yerine ulaştırılıncaya kadar destekleneceği fikridir. Aynı zamanda filmde arka planda, insanları (en azından çok uzun süre) başıboş bırakmayacak bir Tanrı düşüncesi de işlenir. Bununla aslında, insanları yarattıktan sonra başka bir şeye müdahil olmayan Tanrı düşüncesine sahip olan deizme de bir açıdan tepki verilmiş olur.

Son olarak şunu ifade etmek gerekir ki, "The Book of Eli” filmi, dinî mesajların işlenişi ve filmlerde kutsal kitapların değerinin vurgulanmasına iyi bir örnek teşkil etmektedir. Hıristiyan Tanrı, elçi ve kutsal kitap anlayışının doğrudan ve dolaylı olarak izleyiciye aktarıldığı mezkur film, dinî içeriklerin filmlerde araç olarak kullanılmasının yanı sıra dinî bilgi ve mesajların iletilmesinde filmlerden yararlanılmasının değerini de ortaya koyması açısından önemlidir. 
Hakem Değerlendirmesi: Dış bağımsız.

Çıkar Çatışması: Yazar çıkar çatışması bildirmemiştir.

Finansal Destek: Yazar bu çalışma için finansal destek almadığını beyan etmiştir.

Peer-review: Externally peer-reviewed.

Conflict of Interest: The author has no conflict of interest to declare.

Grant Support: The author declared that this study has received no grant support.

\section{Kaynakça/References}

Adam, Baki. Yahudi Kaynaklarına Göre Tevrat. 2. Basım. İstanbul: Pınar Yayınları, 2002.

__. "Yahudilik: Tarihsel Gelişimi, İnanç Esasları ve İbadetleri.” İçinde Yaşayan Dünya Dinleri, editör Şinasi Gündüz, 205-50. Ankara: Diyanet İşleri Başkanlığı, 2007.

Akbaş, Muhsin. "Yahudi ve Hıristiyan Düşüncesinde Ölüm Sonrası Hayat ve Diriliş İnancının Dini ve Teolojik Temelleri.” Dokuz Eylül Üniversitesi İlahiyat Fakültesi Dergisi, sy 41 (2002): 37-60.

Akbay, Okan Haluk. Kojiki: Japon Mitolojisine Bir Yolculuk. Konya: Çizgi Kitabevi, 2014.

Aston, James, ve John Walliss. "The (Un)Christian Road Warrior: The Crisis of Religious Representation in The Book of Eli (2010)." Journal of Religion \& Film 15, sy 1 (2011). https://digitalcommons. unomaha.edu/jrf/vol15/iss1/1.

Aydın, Mahmut. "Hıristiyanlık (Tarihsel Gelişimi, Temel Kaynakları ve Öğretileri).” İçinde Yaşayan Dünya Dinleri, editör Şinasi Gündüz, 77-102. Ankara: Diyanet İşleri Başkanlığı, 2007.

Aydın, Mehmet. "Hıristiyanlık (Kutsal Metinler ve Dini Literatür).” İçinde Diyanet İslam Ansiklopedisi, 17:340-45. İstanbul: Türkiye Diyanet Vakfı Yayınları, 1998.

—. Müslümanların Hristiyanlara Karşı Yazdı̆̆ı Reddiyeler ve Tartışma Konuları. Ankara: Türkiye Diyanet Vakfi Yayınları, 1998.

Balaban, Yüksel. "Miyazaki Sinemasında Şintoizm Göstergelerinin Sunumu.” İçinde Sinema ve Din, 287-308. İstanbul: Dem Yayınlar1, 2015.

Batuk, Cengiz. "Sihizm.” İçinde Dinler Tarihi I-II, 273-300. İstanbul: Lisans Yayıncılık, 2018.

Baybal, Sami. İbrahimî Dinlerde Mesih'in Dönüşü. Konya: Yediveren Kitap, 2002.

Bıyık, Mustafa. Armagedon ve Tanrı Krallı̆̆ı. Ankara: Aziz Andaç Yayınları, 2008.

"Hıristiyan Eskatolojisinde Dünyanın Sonu Kehanetleri." Marife Dini Araştırmalar Dergisi 7, sy 2 (01 Ekim 2007): 163-88.

Bilici, Muhammed Veysel. "Hollywood Filmlerindeki Apokaliptik Temalar: Sinema, Popüler Kültür ve Din." Milel ve Nihal 4, sy 2 (2007): 139-61.

Blizek, William L. "Sinema Filmleri ve Din.” Çeviren Bilal Yorulmaz. Marmara Üniversitesi Ilahiyat Fakültesi Dergisi 47, sy 47 (2014): 193-202.

Bowker, John. The Concise Oxford Dictionary of World Religions. Oxford: Oxford University Press, 2000.

Boz, Mikail ve Dilek Takımcı. "Amerikan Post-Apokaliptik Bilimkurgu Sinemasında Kıyamet İdeolojisi (1924-2000).” Akdeniz Üniversitesi İletişim Fakültesi Dergisi, sy 31 (30 Haziran 2019): 377-403. 
Breimeier, Russ. "The Book of Eli." ChristianityToday.com, 15 Ocak 2010. https://www. christianitytoday.com/ct/2010/januaryweb-only/bookofeli.html.

Bucaille, Maurice. Müsbet İlim Yönünden Tevrat İnciller ve Kur'an. Çeviren Mehmet Ali Sönmez. 7. bs. Ankara: Diyanet İşleri Başkanlığı, 2001.

Çap, Sabri. Goldziher Öncesi Oryantalizm ve Hadis. Ankara: İlahiyat Yayınları, 2019.

Dural, Murat. “Aamir Khan Filmlerinde Dini Öğeler.” Yüksek Lisans Tezi, İzmir Kâtip Çelebi Üniversitesi, 2018.

Ebert, Roger. "The Book of Eli Movie Review.” Erişim 02 Kasım 2019. https://www.rogerebert. com/reviews/the-book-of-eli-2010.

Erbaş, Ali. Hristiyanlık. İstanbul: İnsan Yayınları, 2004.

Güç, Ahmet. Dinlerde Mabed ve İbadet. İstanbul: Ensar Neşriyat, 2005.

Gündüz, Şinasi. Din ve İnanç Sözlüğü. 2. bs. İstanbul: Vadi Yayınları, 2017.

. "Sih Dini.” İçinde Yaşayan Dünya Dinleri, editör Şinasi Gündüz, 373-81. Ankara: Diyanet İşleri Başkanlığı, 2007.

Hallsell, Grace. Tanrıyı Kıyamete Zorlamak: Armagedon, Hıristiyan Kıyametçiliği ve İsrail. Çeviren Mustafa Acar ve Hüsnü Özmen. 2. bs. Ankara: Kim Yayınları, 2003.

Karahan, Harun Dündar. "Hıristiyan Mezheplerinde Vahiy Anlayışı.” Bozok Üniversitesi İlahiyat Fakültesi Dergisi 13, sy 13 (28 Haziran 2018): 287-308.

Karahan, Müge. "Filmler Yalan Söyler mi?” Sabitfikir.com. Erişim 17 Mart 2020. http://www. sabitfikir.com/elestiri/filmler-yalan-soyler-mi\&amp\%3Breferer=81590.

Kaya, Korhan. Lotus Sutra. İstanbul: Sujala Yayıncılık, 2018.

Kutlutürk, Cemil. "Hint Dinleri.” İçinde Dünya Dinleri, editör Şinasi Gündüz, 182-232. İstanbul: Milel \& Nihal, 2019.

Kutsal Kitap. İstanbul: Kitab-1 Mukaddes Şirketi, 2001.

Kuzgun, Şaban. Dört İncil Farklılıkları ve Çelişkileri. 2. bs. İstanbul: Fazilet Neşriyat, 2008.

Küçük, Abdurrahman, Günay Tümer ve Mehmet Alparslan Küçük. Dinler Tarihi. Ankara: Berikan Yayınevi, 2009.

Küçük, Mehmet Alparslan. Kutsal Kitap Anlayışı Yahudilik, Hıristiyanlık ve İslam Örneği. 2. bs. Berikan Yayınevi, 2016.

Okudan, Aysel. "Lotus Sutra ve Budist Kutsal Metinleri Arasındaki Yeri ve Önemi.” Yüksek Lisans Tezi, Ankara Üniversitesi, 2017.

Özkan, Cuma. "Çin Dinleri.” İçinde Dünya Dinleri, editör Şinasi Gündüz, 234-60. İstanbul: Milel \& Nihal, 2019.

Petrakis, John. "The Book of Eli.” The Christian Century, 2010.

Porter, Adam L. "The Book of Eli.” Journal of Religion \& Film 14, sy 1 (2010). https://digitalcommons. unomaha.edu/jrf/vol14/iss1/23.

Pulver, Andrew. "Film Review: The Book of Eli." The Guardian, 14 Ocak 2010, blm. Film. https:// www.theguardian.com/film/2010/jan/14/book-of-eli-film-review.

Sarıkçıŏlu, Ekrem. Dinlerde Mehdi Tasavvurları. Samsun: Sidre Yayınları, 1997.

Spinoza, Benedictus. Teolojik-Politik Inceleme. Çeviren Cemal Bâli Akal ve Reyda Ergün. 4. Bask1. Ankara: Dost Kitabevi, 2016. 
Şen, Murat Tolga. “Tanrının Kitabi : Beyazperde.com Eleştirisi.” Erişim 02 Kasım 2019. http://www. beyazperde.com/filmler/film-128955/elestiriler-beyazperde/.

Şenavcu, Halil İbrahim. “Japon Dinleri.” İçinde Dünya Dinleri, editör Şinasi Gündüz, 262-82. İstanbul: Milel \& Nihal, 2019.

“Tanrının Kitabı (2010) - The Book Of Eli.” Erişim 22 Ekim 2019. https://www.sinemalar.com/ film/21844/tanrinin-kitabi.

“Tanrının Kitabı The Book of Eli.” Erişim 22 Ekim 2019. http://www.sinematurk.com/film/28684tanrinin-kitabi/.

Intersinema.com. "Tanrının Kitabı (The Book of Eli)." Erişim 02 Kasım 2019. https://www.intersinema. com/tanrinin-kitabi-filmi/.

“Tanrının Kitabi." Erişim 22 Ekim 2019. http://www.beyazperde.com/filmler/film-128955/kullanicielestirileri/en-yeniler/.

“The Book of Eli (2010).” Erişim 17 Mart 2020. https://www.imdb.com/title/tt1037705/.

“The Book of Eli (2010).” Erişim 22 Ekim 2019. https://720p-izle.com/izle/altyazi/the-book-of-eli.html.

“The Book of Eli (2010).” Erişim 02 Kasım 2019. https://www.rottentomatoes.com/m/the_book_of_eli.

“The Book of Eli (2010) User Reviews.” Erişim 02 Kasım 2019. http://www.imdb.com/title/tt1037705/ reviews.

Thomas, Edward J. The History of Buddhist Thought. 7. bs. London: Routledge, 1971.

Turan, Süleyman ve Emine Battal. Dünya Dinlerinde Kutsal Metinler. 2. bs. STS Yayınları, 2018.

Tümer, Günay. "Budizm.” İçinde Diyanet İslam Ansiklopedisi, 6:352-60. İstanbul: Türkiye Diyanet Vakfi Yayınları, 1992.

Ünal, Asife. "Uyumlu Bir Dünya İnşası Bağlamında Sinema ve Din İlişkisi: ‘Life of Pi’ Örneği.” International Journal of Sport Culture and Science 3, sy Special Issue 4 (15 Eylül 2015): 567-83.

Ünsal, Gülhanım. "Film Başlıklarının Çevirisi Üzerine Gözlemler." Avrasya Sosyal ve Ekonomi Araştırmaları Dergisi 5, sy 5 (31 Mayıs 2018): 77-92.

Walker, Seth. “'It's not a F****** Book, It's a Weapon!': Authority, Power, and Mediation in The Book of Eli." Journal of Religion \& Film 20, sy 3 (02 Ekim 2016). https://digitalcommons. unomaha.edu/jrf/vol20/iss3/29.

Yitik, Ali İhsan. Doğu Dinleri. İstanbul: İsam / İslam Araştırmaları Merkezi, 2014.

Yorulmaz, Bilal. Sinema ve Din Eğitimi. 2. bs. Dem Yayınları, 2016. 